\title{
Literature Appreciation Teaching Design under the Learning Community Pattern in Higher Vocational Colleges
}

\author{
$\mathrm{Xu} \mathrm{Hu}$ \\ Urban Vocational College of Sichuan \\ Chengdu, China 610101
}

\begin{abstract}
Learning community in higher vocational colleges reflects equality and cooperation, helps teacher-student communication and highlights harmony and intergrowth. The learning community of literature appreciation in higher vocational colleges is focused on interaction in teaching, grasps students' psychological characters, values the social character of teaching contents, arouses students' interest in learning, stresses the experience of teaching modes and cultivates students' comprehensive quality. Based on the learning community pattern, the literature appreciation teaching design in higher vocational colleges is to target a common vision in teaching, create learning scenes closely related to students' lives, advocate a dialogue-based teaching strategy and persist in the intersubjectivity teacher-student relations in order to improve the teaching effect of literature appreciation in higher vocational colleges.
\end{abstract}

Keywords-learning community; class reform; teaching design; scene design

\section{INTRODUCTION}

Learning community consists of learners and facilitators (such as teachers, experts and mentors), where members may help each other through communication and learning resources shared in order to complete a learning task, which establishes an inter-personal relationship between members for mutual influence and promotion. During traditional teaching, teachers and students are members for teaching practice in a classroom, who are easy $\mathrm{t}$ make face to face discussion, forming a learning community spontaneously, such as a learning group, a class or a school, all of which can be a community. And members in the community need to be educated in all regards and ultimately develop students' characters and improve their quality as a whole.

\section{CHARACTERISTICS OF LEARNING COMMUNITY}

The learning community in higher vocational colleges has characters of its own, which is focused on publicity, communication and empathy. It is a student-based new class pattern. Teachers and students, based on life, take class activities as carriers for joint participation of subject knowledge researches, which stress teaching course communication, life of teaching contents, respect students' individual characters, and also emphasize teaching experience and cultivate students' abilities of practice.

\section{A. Keep the Learning System Public}

Course and method for knowledge formation are important goals in class, and students can get educated through reading, exploration, thinking, observation, operation, imagination, questioning and innovation. What teachers pay more attention to are students' emotional life and experience as well as their morality life and personality cultivation, through joint efforts by teachers and students, class activities can become noble life, from which students may get rich life experience.

\section{B. Internal Harmony and Intergrowth in the Learning System}

Learning communities in high vocational colleges lay stress on interaction in teaching and value students' psychological characters. It advocates teacher-student interaction, trust and equality, value students' independent personality and self directedness, keep students' personalities, accept students' personalized thought, make teaching return to what students should be, and students in class can feel their dignity and find what their value is. Especially through the class teaching with harmony and intergrowth, teachers organize and design the class teaching from the height of society and students' development in order to achieve the harmony and intergrowth between real society and students' development through class teaching. Class is a life world where teachers and students have activities and emotions crossed and develop, it can not only develop students' wisdom and abilities but also continuously enrich and improve students' emotional world. In a learning community, the goals of both teachers and students are common vision accepted by every member. Everyone is pursuing vision of his or her own, also struggling from the class (group) vision and keeping each member harmonious and uniform in behavior.

\section{Members' Subjective Behaviors}

During class teaching, through efficiently learning guiding strategy to arose, cultivate and intensify students' independent consciousness, active concept and explorative spirit, teachers hope to enlighten, instruct and guide students to get rid of passive learning, who are expected to actively understand the objective world and knowledge field, for they are generally 
full of passion for exploration, so that they could explore actively and dare to practice, growing and developing healthily.

\section{Keep Teaching Contents Vivid and Stimulate Students' Interests to Learn}

The learning communities organized in higher vocational colleges erect a bridge for education returning to students' life. The learning community is to design teaching scene according to real work course, show specific work post tasks and vocational skills needed, teaching contents are connected with students' real life, make class teaching living, students may experience themselves and complete simulation practice, integrate and intensify theoretical knowledge and practical skills they have. The learning communities in higher vocational colleges provide students with practical teaching scene through real and artificial practices closely related to real life, through which students not only get theoretical knowledge but also grasp professional skills, forming good habits in learning and improving professional quality of their own.

\section{LITERATURE APPRECIATION TEACHING DESIGN UNDER THE LEARNING COMMUNITY PATTERN}

\section{A. Organize Learning Groups}

The basic form of a learning community is group learning but not as simple as a group. Due to characteristics of higher vocational college students, they have weaker foundation than those in universities. Most show great interest and input in professional skill courses and practices. During the teaching of literature appreciation, it is found that it is very important and necessary to organize learning groups by levels. And the most applicable method is to organize groups by quality in a class, which is a basic form. Based on the principle "the same quality between groups, different quality in a group, cooperation between and by those with the same quality, support by those with different quality", all students in a class are grouped. The same quality between groups reflects a balanced development for group learning, set a foundation for fair competition; the different quality in a group creates conditions for cooperation and mutual assistance; the cooperation between and by those with the same quality refers to cooperation between students among groups which make it easy for students to learn and help each other, which reflect learning by levels and push step by step the efficient cooperation and friendly assistance between students.

\section{B. Set up the Common Vision}

The common vision that learning communities are pursuing in higher vocational colleges mainly includes: master professional theory, improve literary accomplishment and train skills. During the literature appreciation teaching, we should give a full consideration to the course characters of vocational education, where professional skill education shall prevail, when improving students' professional skills, we shall also help them shape themselves, intensify literary accomplishment, improve comprehensive quality so as to make students satisfied at self value.

\section{Design Teaching Scene}

According to the training philosophy in higher vocational colleges, it is to center on students, specially cultivate students' professional skills and comprehensive quality and build an important place for students to learn theory and practice in life. And students will undergo class teaching and practice scene set in class, based on students' psychological characters, teachers and students may joint create teaching scenes and diverse task scenes, which integrate theoretical knowledge, literary accomplishment and job demand, connecting brand-new knowledge with what students have mastered, as well as the students' life experience and interests.

The design of literature appreciation teaching scene is based on five regards "scene interest, independent exploration, interaction and doubt solution, summary and inclusion, and applied expansion". According to characters of courses, it adopts four teaching methods "world outlook, doubt and exploration, mass reading and scene once again". Teachers raise questions while talking with students, arrange homework, and provide case research and actual cases so as to stimulate students' thought in information search, analysis and summary. In addition, teachers should design specific collaborative tasks, and during the whole crossing activities, according to learning and communication, content evaluation and group progress, teachers should evaluate the achievements of each group, and combine the course evaluation with the final academic achievements. Besides, teachers can encourage student groups and individuals to continuously conduct self evaluation and mutual evaluation, such evaluation and supervision will play an important in keeping a high level interaction.

\section{Advocate Dialogue Experience}

As for the learning communities in higher vocational colleges, we should lay stress on teacher-student dialogue teaching, and teachers and students may have knowledge, emotion and thought communicated in a atmosphere fair, equal and trust, sharing rights to talk, digging up and creating new knowledge through interaction, in the teaching scene and teaching tasks, pay attention to students' negotiation and interaction. Teachers shall help students solve problems and form thought sparks through dialogue with students, achieving the joint progress in teaching and learning. Therefore, considering students' interest, demand and knowledge they have mastered, teachers shall grasp key points and difficult points in teaching, design a series of topics to attract students in order to finally form an efficient, actively interacting learning community cognitive system on the basis of class dialogue. Within the learning community, teachers and students will complete a dialogue teaching on the basis of mutual respect and acceptance, students change to free expression from traditional listening and to explore knowledge from passive learning and gradually form and create a knowledge structure of their own. Relying on careful organization and dialogues based on active participation, teachers and students can achieve the collision of thoughts and knowledge sharing, which will stimulate sudden knowledge changes and birth of new knowledge systems so that teachers and students can make progress and improve together. Hence, within the learning communities in higher vocational colleges, 
we can carryout dialogue teaching, cultivate experience communication and knowledge sharing in the community, design rich and diverse dialogue scenes, stimulate students to think actively, making students share knowledge and get wised in participation.

\section{E. Persist in Inter-subjectivity}

The learning communities in higher vocational colleges persist in the inter-subjectivity, strengthen teacher-student interaction in teaching, and make teachers become students' leaders and partners, trying best to create a democratic and equal atmosphere in class. The learning community patter is to make all students participate in the class teaching, offering them chances to participate in activities and dialogues, which will improve students' understanding of teaching textual characters, increase students' chances to show works of their own in order to achieve the interaction where teachers teach and students learn through students' participation. Within the learning community, the relations between teachers and students are focused on respect, collaboration, understanding, dialogue and emotional interaction, and a harmonious atmosphere is created between teachers and students, forming the inter-subjectivity, and students achieve the efficient integration of life activity and self development. The intersubjectivity has two points: Understanding and shared understanding between subjects. The understanding indicates that there are differences existing between subjects; the shared understanding indicates the uniformity in communication. The communication is to remove individuality in order to achieve a shared understanding; on the contrary, the true communication shall be based individual equality and mutual respect. The more cares are given between teachers and students, students, the more the support will be and the higher the potential to learn.

\section{CONCLUSION}

The learning community between teachers and students is an elimination and exceeding over traditional especially teachers' dignity-based teacher-student relations, a concentrated expression of teacher-student relations in modern higher education and a basic requirement for modern higher education. Within the learning communities in higher vocational colleges, the teaching of literature appreciation follows the living principle, and an environmental experience teaching pattern is adopted, which has the max effect to stimulate living emotion in teaching, in the meantime, a project research patter is additionally adopted to promote students to learn literature knowledge, based on such teaching and learning, the teaching of literature appreciation becomes more efficient, interesting and active. Students' outlook on life, values and love view are actively and potentially improved through literature during the teaching in order to greatly improve their humanistic quality.

In the meantime, teachers are expected to make more efforts to research learning characters and recognition rules of modern higher vocational college students, and students shall be required to take learning as the first task, and the course design under the learning community in higher vocational colleges is no longer an experience arrangement in brains of teachers, instead the course contents shall respond to students' concern, and the course pattern meets the characters of modern students to receive new knowledge. Respect students, and take problems as mainlines, and students' ability cultivation as the core to create a students-oriented class. While the class teaching effect is improved, the students will have their comprehensive quality increased continuously and the teachers have their professions improved as well.

\section{REFERENCES}

[1] [USA] Peter Senge The Fifth Discipline-The Art \& Practice of Learning Organization [M]. Beijing: CITIC Press, 2009:203.

[2] Feng Jianjun, Life and Education [M] Beijing: Educational Science Publishing House, 2004:184.

[3] Johnson. D.W, Johnson. R. T. Leading the Cooperative School [M] Translated by Tang Zongqing, Shanghai: Shanghai Education Publishing House, 2003:37.

[4] Liu Yunsheng, Analysis of Efficient Chinese Teaching and Literature Education [M]. Chengdu: Sichuan University Press, 2014.

[5] Liu Siwei, Discussion on Strategies of Group Reading Teaching [A]. Study Journal of Modern Education and Teaching Organizational Committee, Collected Papers of Modern Education and Teaching Conferences Mar 2014[C]. Study Journal of Modern Education and Teaching Organizational Committee, 2014

[6] Manabu Sato, Challenges to Schools: Creating a Learning Community [M]. Translated by Zhong Qiquan, Shanghai: East China Normal University Press, 2014. 